\title{
THE ACCENTUATION OF WAYYOMAR IN JOB.
}

What is the reason for the frequent occurrence of "in (accented on the penultimate) in Job?

(I) The word is, of course, the pausal form of רָin? (always accented on the penultimate), and seems to differ from it only as e.g. inquit from lis verbis locutus est. Sometimes both forms occur close together, e.g.

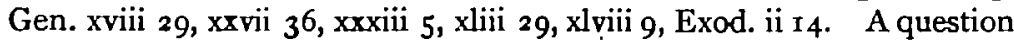
or exclamation is introduced by רֶָ" the answer or rejoinder by

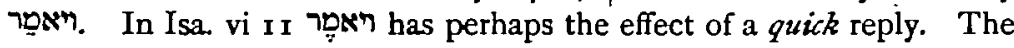
pausal form invariably introduces oratio recta immediately; in 19 passages it is the first word in the verse.

(2) This pausal form occurs 86 times in the O.T. excluding the where it is found 37 times, making a total of 123 occurrences in the O.T. The distribution is varied. Apart from the ת"א it comes oftenest in Gen.-2 I times. Kings is next with 15 , Num. I I, Sam. 20, Judges 7, Exod. 6, Chron. 4, Deut., Jonah, Zech., Dan. 2 each, Joshua, Isa., Amos, Ruth I each. In the n' Prov., and no less than $3^{6}$ times in Job.

(3) The accent, in all books except the $\Omega^{\prime \prime} \mathrm{x}$-and sometimes there also-is on the ultima. It is marked by 'Atnâh 43 times prose and 4

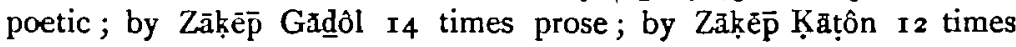
prose and 2 poetic ; by Sēgôltâ 8 times prose and 2 poetic; by Rebîù 7 times prose; by Šalšelet Gădôl 2 times prose; by Pãzẽr I poetic; by 'Olè woyôrëd r poetic. In these 96 occurrences the accent is on the ultima.

(4) But in the following 27 verses in Job the accent is on the penultimate, i.e. in precisely the same position as in the non-pausal form:

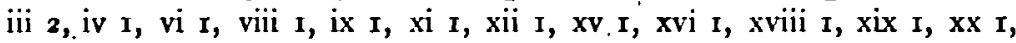
xxi I, xxii I, xxiii I, $x x v$ I, xxvi I, xxvii I, xxix I, xxxiv I, $x x x v$, xxxvi $\mathrm{I}$, xxxviii $\mathrm{I}, \mathrm{xl} \mathbf{I}, 3,6$, xlii $\mathrm{I}$. The form here always occurs just before Sôp Pasûk, and the penultimate has Sillak. The preceding accent is always Rebiå, which according to Wickes ( טעמי אט"ת p. 33 note 25 , and p. 75) should be Rebîa' Muḡrash.

(5) Can the received text be correct in these 27 passages? I am much indebted to the Rev. G. Margoliouth, of the British Museum, for some interesting facts as to the evidence of certain fifteenth- and sixteenth-century MSS and early printed editions where the accent is usually on the ultima. To this may be added the remarkable fact 
noticed by Wickes ( $\Omega^{\prime \prime}$ p. 8) that in the Babylonian (supralinear) punctuation the same accents are used in the ${ }^{\prime \prime}$ as in the other books; consequently the accent there also is on the ultima.

(6) It would thus appear-I quote from Mr Margoliouth's letter' that an examination of the point de nowo is very desirable. A careful survey of the MSS and printed editions might lead to some interesting results'. Perhaps some reader of J.T.S. may care to go into the matter. It will be interesting to consult the Notes in Dr Ginsburg's forthcoming edition for the B. F. B.S.

Meanwhile I would ask whether, if the received text is correct, the unusual accent may not be due to metre and music. Final Pattah before a rolling Rés and a full stop is so naturally stressed as to give the word : spondee'. On the musical character of Robită cf. Wickes; chap. viii.

H. F. B. Compston. 